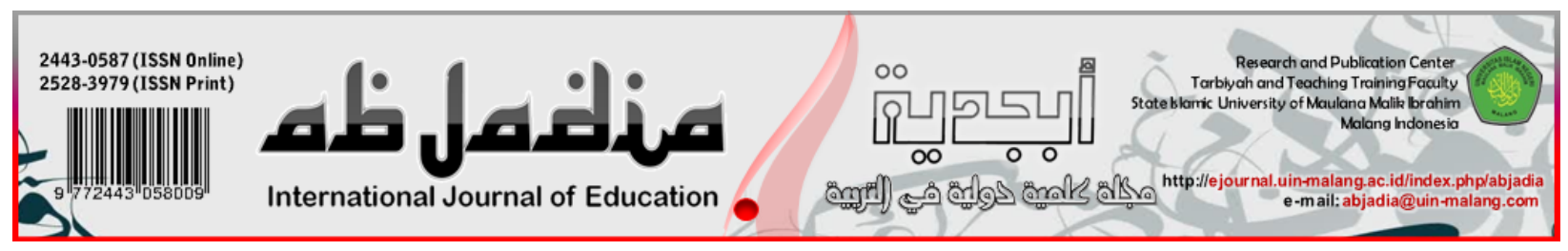

\title{
SIYAHA TOURISM APPLICATION DEVELOPMENT: \\ E-ENCYCLOPEDIA OF ARABIC TOURISM IN MALANG, EAST JAVA, INDONESIA
}

\author{
R. Taufiqurrochman', Agung Prasetiyo² \\ 12 Universitas Islam Negeri Maulana Malik Ibrahim Malang, Indonesia
}

\begin{abstract}
Article History:
Received : 2020-11-24

Revised : 2021-04-24

Accepted : 2021-06-01

Published : 2021-06-30
\end{abstract}

\section{Keywords:}

Encyclopedia, Arabic Tourism, Halal

Tourism, Malang

*Correspondence Address:

taufiq@uin-malang.ac.id

agungprasetiyo@pba.uin-malang.ac.id

\begin{abstract}
The trend growth of travelers abroad from the Middle East, especially from Saudi Arabia, is getting increased. In the year 2019, Indonesia managed to reach rank first tour halal popular world. In the digital era, these things must of course be balanced with a marketing communication strategy that demands an Arabic travel e-encyclopedia. The Siyaha Tourism application developed by researchers is one of the right alternatives. This application is designed and developed using research and development (R\&D) with a Four-D model combined with the procedure for compiling an encyclopedia based on Arabic lexicography. The combination of the media application development process and the preparation of this encyclopedia is a good outcome with complete product specifications, both in terms of content and features. The results of the validation from language, tourism, and culture experts also show that the Siyaha Tourism application in the form of android for mobile and the website www.siyaha.online is worthy of being a media for tourism information, especially tourist destinations in Malang City, East Java, Indonesia which the government has designated as city pilot project of the halal tourism program. 212 respondents rated this product. The results show that the quality of the Siyaha Tourism application is good and needed for tourism.
\end{abstract}

\section{(C) Introduction}

Developments rating of foreign origin of the Middle East, especially from Saudi Arabia, increasingly showing a trend of growth is increasing. In 2014, the recorded number of visits travelers from Saudi Arabia who entered Indonesia through 19 doors entrance main as much as 147 thousand. This number increased by 9.26 percent in 2015 to 160 thousand. Even in the year 2016, the number of visits travelers Saudi Arabia amounted to 186 thousand or grow positively 16.15 percent. (Purnamasari, 2017)

Data Global Muslim Travel Index (GMTI) mentions the number of the rating Muslim world will reach 168 million in the year 2020 with expense at the top of US D 200 billion. Comcec Report (2019) estimates that the growth of Muslim tourists in 2020 will average 9.08 every year. Special to visit tourist origin, Saudi Arabia, to Indonesia, in the year 2018 topped the ranking of unity for the region the Middle East. The Government of Indonesia hopes since the year 2019 rose about 25 percent or 200 thousand people. 
R. Taufiqurrochman, Agung Prasetiyo $\mid \begin{aligned} & \text { Siyaha Tourism Application Development: } \\ & \text { E-Encyclopedia of Arabic Tourism in Malang, East Java, } \\ & \text { Indonesia }\end{aligned}$

(Masrafi, 2019) CNN Indonesia proclaims that in the year 2019, Indonesia and Malaysia managed to occupy rank first tour halal popular world. (Indonesia, 2019)

From an economic point of view, this fact benefits Indonesia. According to Nia Undoubtedly, Deputy Field of Marketing of Tourism II, spending on average travellers from the Middle East reached 2200 USD or nearly 2 times as much from the average expenditure across the rating that contributes to the increase of foreign exchange of the country. (Nauly, 2019) every plant is in line with the increase in industrial halal (Samori, Salleh, \& Khalid, 2016) and the number of interest travelers abroad against halal tourism which is a halal lifestyle, a selection of service that is based on the concept of halal. (Battour \& Ismail, 2012) In the case of halal tourism is, according to Hasan Gaido, President of Indonesia Saudi Arabia Business Council (ISABC), the Government of Indonesia is too late for yet serious work on the potential of halal tourism. (Kelana, 2017) Halal Tourism should continue to be promoted through various media and cooperation with various parties, as well as disseminated by the massif through several studies or research and development that produces a variety of product support. (Satriana \& Faridah, 2018)

The need of the material promotion of travel, especially the content Arabic lodging for travelers origin of the Middle East, becoming a factor prime which encourages researchers for developing products digitally in the form of e-encyclopedia of travel to speak Arabic which contains a variety of information tour that continues to evolve rapidly, ranging from travel destinations nature, travel religion, travel culinary, tourist villages, tourist education, and so forth. The researcher's choice is also related to the strategy of marketing communication that in the digital age, efforts to promote a brand (brand) was not able to escape from the digital media and the internet (network interconnection). (Achyar, 2015)

The lack of travel information media in Arabic into obstacles serious must be immediately addressed to be effective in exciting the interest rating of foreign origin of the Middle East. With the e-encyclopedia of travel Air languages Arabic, they will receive information about tourism in Indonesia more clearly and quickly. Development of the product e-encyclopedia of travel Air languages Arabic is in line with the program of etourism which has prepared the Government of Indonesia since 2015 last. According to the Minister of Tourism Arief Yahya, means digital becomes a means of promotion are good. (Achyar, 2015)

One of the representative destinations that contain a variety of tours is the Greater Malang area because East Java province has been designated as one of the nine provinces of halal tourist destinations in Indonesia which must comply with the Halal standards of the Indonesian Ulema Council (MUI). (Achyar, 2015) Also, the city of Malang is nicknamed Parijs van Oost-Java or the city of Paris from East Java (Alfri, 2016) because it has more than 110 tourist destinations. (Admin, 2019) It is certainly going to add a visit to travelers to Malang. In the year 2016 then, the number of travelers Domestic to Malang 
reached 3,987,074 people, while travelers abroad number 9535 people. (Sasongko, 2017) This number continues to increase from year to year, including tourists from the Middle East.

Based on the facts above, the researchers managed to identify three issues fundamentally related to the importance of the development of the application of the Arabic encyclopedia. First, Indonesia Tourism, especially halal tourism and rating foreign origin of the Middle East, still need to continue disseminated through various media, collaboration, and research that produces a variety of products. Second, the amount of content travel to speak Arabic is still minimal so it becomes a constraint that must be immediately addressed by the strategy of marketing communication -based digital to be more effective in exciting the interest rating of foreign origin of the Middle East. Thirdly, there are no tourist guides in Arabic for destination travel in Malang, whereas the city of Malang is one of the pilot projects for tourist halal in Indonesia.

In the research and development of products is, formulated some questions, namely: (1) how the process of developing the Siyaha Tourism application: eencyclopedia of Arabic Tourism? (2) How do the results of the validation of the experts on the Siyaha Tourism application? (3) How is the perception of the users of the Siyaha Tourism application?

\section{[Q] Method}

\section{RED Research Design and Procedures}

This research is a Research and Development (R\&D) at level 4 because it tries to create a product that has never existed before. (Sugiyono, 2010) The development procedure that is used in research $\mathrm{R} \& \mathrm{D}$ is the $4 \mathrm{D}$ model (Four-D), which was initiated by Thiagarajan. (S., Semmel, \& Semmel, 1974) Four stages it is Define, Design, Develop, and Disseminate. (Buhari, 2011) Here are pictures of stages of R\&D with the Four-D Model.

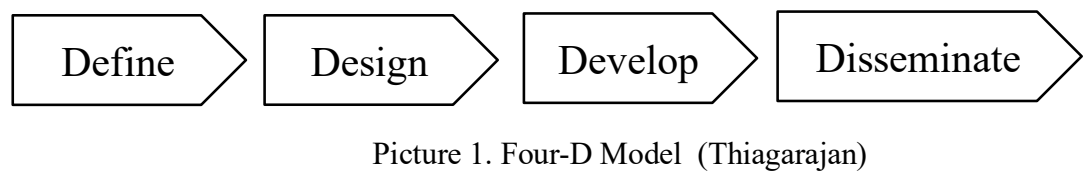

Apart from being an Android-based model application, the content of this product is also based on an encyclopedia and has the nuance of an article website or blog. Because of it, the researchers also followed the standard of the procedure in the preparation of the encyclopedia based lexicography Language Arabic initiated by Ali Al Qosimi. (alQosimi, 1991) Procedure lexicography was followed by five stages, namely: collect material, determine systematic encyclopedia, translation contents, writing, and publishing products. Here's a picture stage preparation of encyclopedia language Arabic. 
\begin{tabular}{l||l} 
R. Taufiqurrochman, Agung Prasetiyo & $\begin{array}{l}\text { Siyaha Tourism Application Development: } \\
\text { E-Encyclopedia of Arabic Tourism in Malang, East Java, } \\
\text { Indonesia }\end{array}$
\end{tabular}

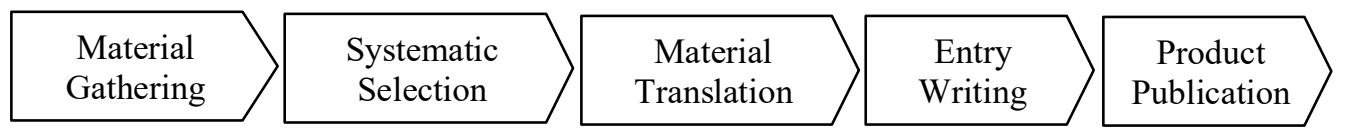

Picture 2. The Stage of composing the Arabic encyclopaedia by Ali al-Qosimi

\section{Data Collection Techniques}

1. Types of Data

Data consists of qualitative and quantitative. Qualitative data form of suggestions and criticisms from the expert media, expert contents (expert language and observers travel). Quantitative Data form of scores and ratings of products were listed in the questionnaire that in sharing.

2. Data Collection Instruments

The instrument in the form of questionnaires was distributed to the respondents, namely: expert media, expert design, and users. Before making the instrument, the researcher compiled a grid that contained an overview of the relationship between the evaluation target objects, instruments, numbers, and the number of items in the instrument. (Arikunto \& Jabar, 2009) In addition to questionnaires, researchers also use sheets of observations, references, and documents are related to the content encyclopedia

\section{Products Test}

The product test aims to know the level of the feasibility of application products. Product test into the terms of research development so that researchers can deduce whether the products are produced really good quality, proper use, and proper target. Test design tries to use the methods of experimental One-Shot Case Study. (Sugiyono, 2010) The paradigm in this experimental research model is described as follows.

$\mathrm{X} \mathrm{O}$

Remarks:

$X=$ Treatment (treatment) given (independent variable)

$\mathrm{O}=$ Observation (dependent variable)

\section{Test Subjects}

Type the sample is purposive with consideration criteria particular, namely: 1) the application of Android; 2) tourists in Malang; 3) learner language Arabic, and 4) users who require the free tour speaking Arabic -based Android. Selection of the type of sample is purposive is already by the state of the population that are not limited to (infinite) because the application is not able to set limits. Although Thus, research is trying to pick a sample from the source of the data or population that is heterogeneous, from elements of academics and the general public. The number of this purposive sample is more than 200 people. 


\section{Data Analysis Techniques}

The steps in analyzing data are:

(1) Changing the assessment of qualitative into quantitative through the process of scoring, while the data quantitative allowed accordance scores were obtained. The scale used is a Likert scale model (Sugiyono, 2009) with a range of answers to numbers that are considered appropriate. The range of numbers that is $5=$ very good, $4=$ good, 3 = sufficient, 2 = less, 1 = very less.

(2) The results of the questionnaire were analyzed by calculating the presentation of the value that is obtained from each indicator, namely the number of grades throughout each indicator is divided by the number of maximum and multiplied by 100 percent (Susanto, 2012) with the formula below.

$$
\rho=\frac{f}{N} \times 100 \%
$$

Remarks:

$$
\begin{aligned}
& \rho=\text { Percentage } \\
& f=\text { Frequencies are being sought or score that is obtained } \\
& N=\text { Number of Cases or maximum score }
\end{aligned}
$$

(3) furthermore, the percentage was referred to as the criteria of assessment as follows.

\begin{tabular}{|clc|}
\hline Assessment & & Criteria \\
$80 \%-100 \%$ & $=$ & very good \\
$60 \%-79.99 \%$ & $=$ & good \\
$40 \%-59.99 \%$ & $=$ & sufficient \\
$20 \%-39.99 \%$ & $=$ & less \\
$0 \%-19.99 \%$ & $=$ & very less \\
\hline
\end{tabular}

Picture 3. Percentage dan Assessment Criteria

With this categorization, the quality of research products can be known.

(4) In the first, researchers plan on deploying a questionnaire in three ways: conventional (face to face), online (Google Form), and online data on Play Store. However, because of the situation of pandemic Covid-19, the researchers chose the deployment questionnaire only through Google Forms are online.

\section{Result}

The Siyaha Tourism development process consists of two processes, namely: the application development process and the encyclopedia development process.

\section{Application Development Process}

The process of development of applications of e-encyclopedia of travel language Arab named Siyaha Tourism is through several stages. 
\begin{tabular}{l||l} 
R. Taufiqurrochman, Agung Prasetiyo & $\begin{array}{l}\text { Siyaha Tourism Application Development: } \\
\text { E-Encyclopedia of Arabic Tourism in Malang, East Java, } \\
\text { Indonesia }\end{array}$
\end{tabular}

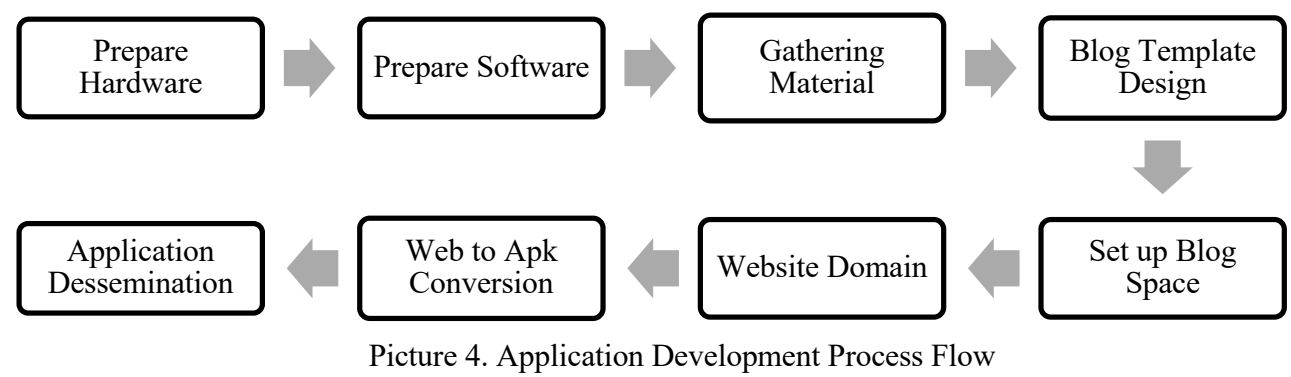

First, prepare the hardware that appropriate specifications that are needed in producing applications based on Android, such as laptops, computers, smartphones, printers, and scanners.

Second, set up the software, among others: Operation System Android, Operating Systems Windows, and MacBook, PicsArt, Appsgeyser, Google Drive, Google Forms, Gmail, Chrome Browser Ms. Office 365 (Word, Excel), IBM SPPS Statistics version 23, YouTube Studio, Camtasia, Blogger, Blogspot Templates, Google Meet, Zoom, Media Converter, Snapshot, Notepad.

Third, collect materials or materials in the application. This material is a multimedia element of the text, images, animation, audio, and video. The materials are collected, selected, and grouped according to the theme, then edited using software according to their use.

Fourth, plan to design a website that begins with selecting a template Blogspot are by the objectives and needs. Some templates are selected and tested to determine their reliability by the criteria that are set. Criteria template well include quality background, clear navigation, selection of good fonts, the informative sidebar, fast loading, SEO friendly, the function of the plugin, language, ease of editing, and so on.

Fifth, arrange the space on the blog according to the material and travel theme. Furthermore, to prepare the template article that all writings or info on upload have quality are good as a title that is clear and concise, articles concise and easy to understand, the placement of the image, and so on.

Sixth, after the blog version has been designed and completed with its contents, the blog will be published with the address (https://siyahaarabia.blogspot.com). Next, the researcher selects and buys a representative domain name. The domain name that was selected is www.siyaha.online with extensions [dot] online are relatively new and the price is affordable. Then, the redirect process starts, which is the process of switching the domain name from [dot] Blogspot to [dot] online.

Seventh, researchers build applications based on android with how to convert the pages websites into apps android extension [apk]. This method was chosen by researchers because it is easier and more practical than starting production from android maker software such as Android Studio. How conversion website to android is, the price is cheap and the process is much faster. 
Eighth, the process of dissemination of the products or the publication of the application Siyaha Tourism with a way to upload files apk into account Google Drive Siyaha. After that, the link files on Google Drive be shortened so that easily remembered by the user when going to download the application apk. File application Siyaha Tourism can be accessed or downloaded by way of click http://bit.ly/siyaha

\section{Encyclopedia Development Process}

In the application of Siyaha Tourism, there is an encyclopaedia or dictionary language that contains the terms of tourism. Dictionary is comprised of dictionary language Arabic dictionary language of Indonesia, dictionary language of English, and the dictionary language Java. Besides, the Siyaha Tourism application is also equipped with download facilities so that users find it easy to download reference books about tourism. This facility is similar to a library. The number of available books is still nine titles of books. This amount can still be added through a periodic update process.

The process of compiling an encyclopedia in the Siyaha Tourism application is the same as the process of compiling a dictionary in general. Process stages of preparation of the encyclopedia consist of six stages, namely: 1) determine the purpose and choose the approach; 2) determine the type and type of encyclopedia; 3) search and collect references as data corpus; 4) choose a systematic encyclopedia arrangement as needed; 5) writing encyclopedia material/content; 6) dissemination or encyclopedia publication.

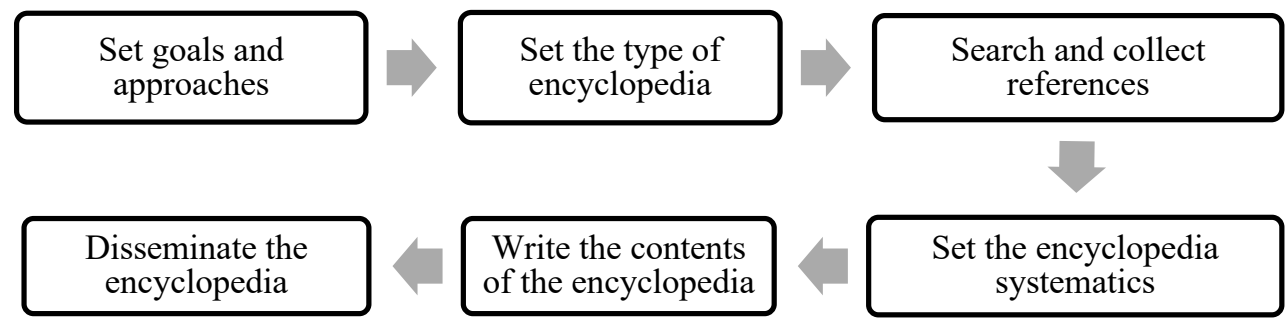

Picture 5. Encyclopaedia Development Process Flow

\section{Product Specifications and Features}

The following are product specifications and their features.

\begin{tabular}{|c|l|l|}
\hline No & \multicolumn{1}{|c|}{ Description } & \multicolumn{1}{c|}{ Explanation } \\
\hline a. & Product Name & Siyaha Tourism \\
\hline b. & $\begin{array}{l}\text { Product } \\
\text { Description }\end{array}$ & $\begin{array}{l}\text { Siyaha Tourism is a mobile and website -based application developed with } \\
\text { an e-encyclopedia approach and in Arabic, English, and Indonesian. } \\
\text { Applications This contains b orgasm destination tourism in Malang, East } \\
\text { Java, Indonesia. One of the cities that is a pilot project for Halal Tourism in } \\
\text { Indonesia }\end{array}$ \\
\hline c. & Compiler & $\begin{array}{l}\text { 1. Dr. H. R. Taufiqurrochman, MA } \\
\text { 2. Agung Prasetiyo, M.Pd }\end{array}$ \\
\hline
\end{tabular}


R. Taufiqurrochman, Agung Prasetiyo $\mid \begin{aligned} & \text { Siyaha Tourism Application Development: } \\ & \begin{array}{l}\text { E-Encyclopedia of Arabic Tourism in Malang, East Java, } \\ \text { Indonesia }\end{array}\end{aligned}$

\begin{tabular}{|c|c|c|}
\hline d. & $\begin{array}{l}\text { Application } \\
\text { Info }\end{array}$ & 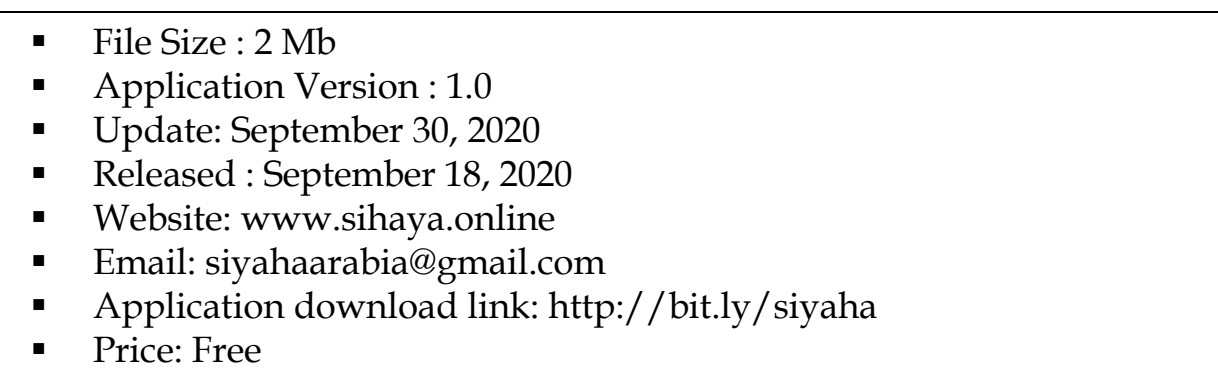 \\
\hline e. & $\begin{array}{l}\text { Application } \\
\text { Logo }\end{array}$ & \\
\hline f. & $\begin{array}{l}\text { Applications } \\
\text { Features }\end{array}$ & $\begin{array}{l}\text { 1. Graphic Info Malang } \\
\text { 2. Material about various tourist destinations } \\
\text { 3. Encyclopedia or Dictionary of Arabic, English, Indonesian, Javanese } \\
\text { 4. About the History of Malang } \\
\text { 5. Travel List (List Travel ), containing } 150 \text { destinations travel ranging } \\
\text { from beaches, waterfalls, sources of water, museums, parks, hills, } \\
\text { caves, where recreation, village tour, tour culinary, temples, forests, } \\
\text { reservoirs, hobby, travel culture, etc. } \\
\text { 6. Map of Malang } \\
\text { 7. Video List } \\
\text { 8. Pustaka Download contains tourism books } \\
\text { 9. Contact: feature to send messages from users to application developers } \\
\text { 10. Translate from Google, automatic translation of blog content covering } \\
\text { more than } 80 \text { languages. } \\
\text { 11. Popular; featuring articles most much accessible. } \\
\text { 12. Search: Search for travel themes and so on } \\
\text { 13. Keyword; said key articles on destinations travel } \\
\text { 14. External link, connecting to the official website of Malang city } \\
\text { government, Malang Regency, Batu city, UIN Malang. } \\
\text { 15. Social Media } \\
\text { 16. Curriculum Vitae contains a curriculum vitae from the application } \\
\text { developer Siyaha Tourism }\end{array}$ \\
\hline
\end{tabular}

Table 1. Product Specifications and Features

\section{The Results of The Media Expert's Validation}

In assessing this product, researchers involved 2 experts. First, experts in the field of media and android applications; second, experts in the field of networking and websites. The following is a table of assessments or validations from expert 1 and expert 2 regarding the quality of the application.

\begin{tabular}{|l|c|c|c|c|l|}
\hline Desain Visual & Expert 1 & Expert 2 & Amount & Average & Category \\
\hline 1. Pictures & 5 & 5 & 10 & 5 & Very good \\
\hline 2. Template colors & 4 & 5 & 9 & 4,5 & Very good \\
\hline 3. Font (Arabic and Latin) & 4 & 4 & 8 & 4 & Good \\
\hline 4. Logo & 5 & 5 & 10 & 5 & Very good \\
\hline
\end{tabular}



Indonesia

\begin{tabular}{|c|c|c|c|c|c|}
\hline 5. Name & 5 & 5 & 10 & 5 & Very good \\
\hline 6. Animation & 4 & 3 & 7 & 3,5 & Good \\
\hline \multicolumn{6}{|l|}{ Time } \\
\hline 7. Speed of Loading Time & 3 & 4 & 7 & 3,5 & Good \\
\hline 8. Download Time Speed & 4 & 3 & 7 & 3,5 & Good \\
\hline \multicolumn{6}{|l|}{ Interactivity } \\
\hline $\begin{array}{l}\text { 9. Communication with Admin } \\
\text { (Feature: Send Message) }\end{array}$ & 4 & 3 & 7 & 3,5 & Good \\
\hline 10. Reader's Comment Column & 4 & 4 & 8 & 4 & Good \\
\hline \multicolumn{6}{|l|}{ Content } \\
\hline $\begin{array}{l}\text { 11. Completeness of Tourist } \\
\text { Information }\end{array}$ & 5 & 5 & 10 & 5 & Very good \\
\hline $\begin{array}{l}\text { 12. Language (Arabic, English, } \\
\text { Indonesian) }\end{array}$ & 4 & 4 & 8 & 4 & Good \\
\hline 13. Encyclopaedia Vocabulary & 4 & 4 & 8 & 4 & Good \\
\hline $\begin{array}{l}\text { 14. Composition of Table of } \\
\text { Contents }\end{array}$ & 5 & 5 & 10 & 5 & Very good \\
\hline 15. Download facility & 5 & 4 & 9 & 4,5 & Very good \\
\hline \multicolumn{6}{|l|}{ Access } \\
\hline 16. Ease of Access & 4 & 3 & 7 & 3,5 & Good \\
\hline 17. Instructions for use & 3 & 3 & 6 & 3 & Enough \\
\hline 18. Utilization of Links & 3 & 4 & 7 & 3,5 & Good \\
\hline \multicolumn{6}{|l|}{ Compatibility } \\
\hline 19. Compatible with hardware & 5 & 5 & 10 & 5 & Very good \\
\hline 20. Can be opened in all browsers & 5 & 5 & 10 & 5 & Very good \\
\hline 21. Compatible Operating System & 5 & 5 & 10 & 5 & Very good \\
\hline \multicolumn{6}{|l|}{ Functionality } \\
\hline 22. Completeness of Features & 4 & 5 & 9 & 4,5 & Very good \\
\hline 23. Key Functions & 3 & 3 & 6 & 3 & Enough \\
\hline \multicolumn{6}{|l|}{ Usability } \\
\hline 24. Ease of use & 4 & 4 & 8 & 4 & Good \\
\hline 25. Needs to access tourist info & 5 & 5 & 10 & 5 & Very good \\
\hline
\end{tabular}

Table 2. Media Validation Results

\section{The Results of The Content Expert's Validation}

In assessing this product, researchers involved 2 experts. First, experts in the field of Arabic language and culture; second, an expert in the language of English and tourism. The following table assessment or validation of experts 1 and experts 2 on the content products.

\begin{tabular}{|l|c|c|c|c|c|}
\hline Material (Content) & Expert 1 & Expert 2 & Amount & Average & Category \\
\hline 1. Presentation of Article Title & 4 & 5 & 9 & 4,5 & Very good \\
\hline 2. Keywords or Tags & 5 & 5 & 10 & 5 & Very good \\
\hline 3. Determining the Theme of Tourism & 5 & 5 & 10 & 5 & Very good \\
\hline
\end{tabular}


R. Taufiqurrochman, Agung Prasetiyo $\mid \begin{aligned} & \text { Siyaha Tourism Application Development: } \\ & \text { E-Encyclopedia of Arabic Tourism in Malang, East Java, } \\ & \text { Indonesia }\end{aligned}$

\begin{tabular}{|l|c|c|c|c|l|}
\hline 4. Completeness Info Destinations & 4 & 5 & 9 & 4,5 & Very good \\
\hline 5. Audio-Visual Material & 4 & 4 & 8 & 4 & Good \\
\hline 6. Correctness of Data and Information & 5 & 4 & 9 & 4,5 & Very good \\
\hline 7. Data and Information Update & 5 & 4 & 9 & 4,5 & Very good \\
\hline Language & & & & & \\
\hline 8. Arabic Translation & 5 & 4 & 9 & 4,5 & Very good \\
\hline 9. English Translation & 4 & 3 & 7 & 3,5 & Good \\
\hline 10. Vocabulary Selection & 5 & 4 & 9 & 4,5 & Very good \\
\hline 11. The Truth of Language Grammar & 5 & 4 & 9 & 4,5 & Very good \\
\hline 12. Writing Script & 5 & 4 & 9 & 4,5 & Very good \\
\hline Implementation & & & & & \\
\hline 13. Compliance need users & 4 & 4 & 8 & 4 & Good \\
\hline 14. Accordance with the media users & 4 & 4 & 8 & 4 & Good \\
\hline 15. Easy to use & 4 & 4 & 8 & 4 & Good \\
\hline
\end{tabular}

Table 3. The Results of The Content Expert's Validation

\section{Results Ratings User Products}

There are 20 questions in the questionnaire that consisted of five questions commonly related to travel and 15 questions specifically related to the products that are developed, researcher. There are 212 users or respondents who are willing to answer the questionnaire. In terms of the type of sex, men 87 people $(41 \%)$ and women $125(59 \%)$. From the terms of the place of origin, respondents from the city of Malang, 79 (37\%), respondents from outside the city of Malang, 133 (63\%). From the aspect of the profession, teachers or lecturers 18 people $(8 \%)$, students or student 158 people $(75 \%)$, people commonly $36(17 \%)$.

Following are the results of the assessment of respondents or product users and the scoring.

\begin{tabular}{|c|l|c|c|c|c|c|c|}
\hline \multicolumn{2}{|l|}{} & \multicolumn{5}{|c|}{ Score } & amount \\
\hline General Inquiries (Travel): & 1 & 2 & 3 & 4 & 5 & Respondents \\
\hline 1 & Feelings of Traveling in Malang City & 4 & 17 & 33 & 74 & 84 & 212 \\
\hline 2 & Duration of traveling in Malang City & 9 & 12 & 62 & 75 & 54 & 212 \\
\hline 3 & The role of mobile applications around travel info & 18 & 23 & 35 & 78 & 58 & 212 \\
\hline 4 & The role of the website around tourist info & 19 & 21 & 25 & 68 & 79 & 212 \\
\hline 5 & The Need for Halal Tourism & 10 & 12 & 59 & 64 & 67 & 212 \\
\hline Special Questions (Application/Website) & & & & & & \\
\hline 6 & Logo and Name & 3 & 9 & 21 & 77 & 102 & 212 \\
\hline 7 & Visual Display (Image, Colour, Animation) & 7 & 13 & 36 & 66 & 90 & 212 \\
\hline 8 & Font (Arabic and Latin) & 9 & 17 & 41 & 59 & 86 & 212 \\
\hline 9 & Loading Speed & 8 & 15 & 39 & 80 & 70 & 212 \\
\hline 10 & Application Installation & 6 & 14 & 39 & 99 & 54 & 212 \\
\hline
\end{tabular}




\begin{tabular}{|c|l|c|c|c|c|c|c|}
\hline 11 & Ease of use of the application & 10 & 16 & 40 & 59 & 87 & 212 \\
\hline 12 & Language Translation (Arabic and English) & 6 & 10 & 36 & 80 & 80 & 212 \\
\hline 13 & Arabic Encyclopaedia & 5 & 14 & 41 & 64 & 88 & 212 \\
\hline 14 & Complete Travel Information & 5 & 13 & 27 & 76 & 91 & 212 \\
\hline 15 & Update of Data and Information & 18 & 22 & 45 & 62 & 65 & 212 \\
\hline 16 & Travel Info is easy to understand & 13 & 19 & 42 & 60 & 78 & 212 \\
\hline 17 & Completeness of Application / Website Features & 7 & 14 & 47 & 62 & 82 & 212 \\
\hline 18 & Compatible with the device & 2 & 4 & 7 & 64 & 135 & 212 \\
\hline 19 & Interactive (Message and Comment Features) & 3 & 8 & 37 & 89 & 75 & 212 \\
\hline 20 & Required by the user & 4 & 7 & 33 & 102 & 66 & 212 \\
\hline
\end{tabular}

Table 4. The Respondent's Assessment of The Product

\section{i㬏 Discussion}

\section{Product Development Process}

There are 2 processes the researcher has taken in developing a product called Siyaha Tourism, an Arabic encyclopedia that contains information on tourism in Malang, East Java, Indonesia. First, the application development process in the form of websites (blog articles) and mobile android. Second, the process of compiling an encyclopedia as content or material for tourism and language information.

In the application development process, there are 8 steps, namely: 1) hardware preparation, 2) software preparation, 3) material collection in the form of multimedia elements, 4) planning website design, especially templates, 5) managing space and its features 6) creating a domain (www.siyaha.online) and publish it, 7) convert website pages into android applications (.apk), 8) disseminate android -based products.

These eight steps are relatively more quickly because the researchers did not start the process of developing android with application design and wake android in general like Android Studio that requires a process of coding and so forth. Here, the researcher starts the development process of android is the first advance of designing a blog or website, and then convert the page website that making the process much faster and easier. In this way, researchers can produce media: an android application (called Siyaha Tourism, an apk type) and a website page (located at www.siyaha.online).

Second, the encyclopedia development process consists of 6 stages, namely: 1) determining goals and choosing an approach; 2 ) set the type and type of dictionary; 3 ) search and collect references as data corpus; 4) choosing a systematic dictionary arrangement according to the goals and needs; 5) writing the material/contents of the dictionary; 6) dissemination or publication of an encyclopedia. Stages have developed researchers from 5 stages standard in the preparation of the encyclopedia language Arabic according to Ali al-Qasimi. 
\begin{tabular}{l||l} 
R. Taufiqurrochman, Agung Prasetiyo & $\begin{array}{l}\text { Siyaha Tourism Application Development: } \\
\text { E-Encyclopedia of Arabic Tourism in Malang, East Java, } \\
\text { Indonesia }\end{array}$
\end{tabular}

\section{Product Validation}

Product validation by experts also goes through 2 processes; validation of media aspects and validation of content or material aspects by involving 2 experts in each process. First, validation of products from the aspect of media and technology in table 2 indicates that the products are developed researcher, the quality is very good with the value of an average of 84 percent. Rate this includes the design of a visual, time (time), interactivity, content ( materials ), access, compatibility, functionality, and usability.

Secondly, the validation of products from the aspect of the content or materials that involve the language and tourism are shown in Table 3. The result shows that from the language aspect the score is 91 percent (very good). Meanwhile, regarding tourism information, worth 84 percent (very good). In conclusion, the content or material of the Siyaha Tourism application is very good with an average value of 87 percent. The materials are rated include three aspects: the content (material travel), linguistic, and enforceability.

\section{Product User Response}

Table 4 contains the results of scoring and rating the user's application as many as 212 respondents. The results show that 39\% feel very happy and 35\% feel happy traveling in Malang. Figures this indicates that the destination travel in Malang has the power pull that captivates the hearts of users and regards it is of capital importance that the development of world tourism in Malang. Regarding Android-based mobile applications, users consider that this kind of application is important and necessary. $27 \%$ answered very importantly and 37\% answered importantly. While on the website www.siyaha.online, known as much as $37 \%$ of respondents admitted that very need and $32 \%$ claimed to need the website specifically that contains information about tourism in Malang. Regarding Halal Tourism, 31\% of respondents admitted that it was very necessary and 30\% admitted that there was a need for halal tourism in Malang. Interests of the respondents to travel halal is of course only the value of a positive for world tourism Indonesia, especially in Malang which since 2019 is set as a pilot project for the development of tourist halal in Indonesia.

It important on applications encyclopedia travel is the completeness of the content or material information that is presented. $43 \%$ of respondents assess tourism information in the application is very complete and $36 \%$ assess the full. This data shows that the Siyaha Tourism application has met encyclopedia standards, one of which is characterized by the completeness of the content. There are 150 destinations travel which is written in the application of this. Variety of destinations it also has been mapped into several clusters travel, for example, travel nature like beaches, waterfalls, caves, sources eyes water, hills, and so forth. Also, the tourist culture and education such as museums, tourist religion, travel culinary, where recreation and pool swimming, travel-related hobbies such as paragliding, camping, and so on. 
In conclusion, from the 20 questions asked to 212 respondents to assess the product from the tourism aspect and the media aspect, it is known that this product has received very positive appreciation. The result shows $38 \%$ of respondents said it was very good and $34 \%$ of respondents said it was good. This means that Siyaha Tourism products are in a good rating index.

\section{Conclusion}

First, process development of applications Siyaha Tourism is divided into two processes, namely: process engineering wake up the application and the process of filling the content application. The process of designing wake up applications through eight stages, namely: 1) the preparation of hardware, 2) preparation software, 3) preparation of material multimedia, 4) design blog template, 5) design space blog, 6) choose a web domain, 7) converting from a website to android apk application. While the process of filling the content application adheres 6 stages of preparation of the encyclopedia in science lexicology-lexicography languages Arabic, namely: 1) determine the purpose and approach, 2) choose the type and the type of encyclopedia, 3) look for references and materials, 4) establish a systematic, 5) translate and compiling materials, 6) product dissemination.

Second, the product validation process goes through two validation stages; the validation of media and the validation of the content. Validation media by two media experts judging from the aspect of mobile-based applications and websites. The results show media experts (android) rate Siyaha Tourism products by $85 \%$ which means very good; while the media expert (website) rated it as $84 \%$ which means it is also very good. So, from the media aspect, Siyaha Tourism is a very good product and deserves to be tested by the public. Meanwhile, content validation was also assessed by 2 people, the first was an expert in the field of language, and the second in the field of tourism. Expert languages assess product Siyaha Arabia amounted to 91\%, which means very good, while expert tour assets amounted to $84 \%$ is very good. In conclusion, the product application Siyaha Tourism got a mean $87 \%$ or very good from the content of the encyclopedia as well as articles about the info travel.

Thirdly, Siyaha Tourism has been released and published to be rated by the user. 212 respondents filled out a questionnaire to rate this product. They consist of $41 \%$ male and 59\% female. Respondents from outside Malang as much as $63 \%$ and from inside Malang as much as 37\%. In the questionnaire, there are 20 questions: 5 questions related to tourism and 15 related to Siyaha Tourism. The data obtained show that $38 \%$ of respondents rated it very well and $34 \%$ considered it good. If calculated, this figure becomes $72 \%$ which in the product criteria index is in the range of $60 \%-79.99 \%$ which means that Siyaha Tourism is good. The product has the potential to be developed with continuously updated and revised to forward more and meet the expectations of the users, especially the rating both domestic and foreign, especially from the Middle East. 
\begin{tabular}{l||l} 
R. Taufiqurrochman, Agung Prasetiyo & $\begin{array}{l}\text { Siyaha Tourism Application Development: } \\
\text { E-Encyclopedia of Arabic Tourism in Malang, East Java, } \\
\text { Indonesia }\end{array}$
\end{tabular}

\section{Acknowledgment}

Acknowledgment is addressed to to the Ministry of Religion of the Republic of Indonesia and the Institute for Research and Community Service, State Islamic University of Maulana Malik Ibrahim Malang.

\section{Bibliography}

Achyar, M. (2015). Digital Marketing Strategy: Indonesia Halal Tourism. Retrieved July 25, 2019, from the KOMPASIANA website:

https://www.kompasiana.com/mahfud.achyar/55a105ceef927355068b456a/stra tegi-digital-marketing-indonesia-halal-tourism

Admin, W. (2019, January 18). 110 Points Travel in Malang Latest whose Again Hits 2019-Explore Malang. Taken July 25, 2019, from the Complete Travel website: https://wisatalengkap.com/tempat-wisata-malang-terbaru-bagus-dan-wajibdikunjungi/

al-Qosimi, A. (1991). Ilm al-Lughah wa Shinaah al-Mu'jam. Mekah: Jami' ah al-Malik Saud. Retrieved from https://ia802304.us.archive.org/27/items/Elm-aloga-wasena3atAl-mo3jam/Elm-aloga-wa-sena3atAl-mo3jam.pdf

Alfri. (2016, April 8). 60 Tourist Destinations in Malang, A City That Is Okay to Have. Taken July 25, 2019, from the Traveling Yuk website: https://travelingyuk.com/wisata-malang-kota/13797/

Arikunto, S., \& Jabar, C. S. A. (2009). Evaluation of Educational Programs: Practical Theoretical Guidelines for Students and Educational Practitioners Jakarta: Bumi Aksara.

Battour, M., \& Ismail, M. (2012). The Mediating Role of Tourist Satisfaction: A Study of Muslim Tourists in Malaysia. Journal of Travel and Tourism Marketing, 29(3), 279297.

Buhari, B. (2011, August 25). Four-D Model ( Learning Tool Development Model from Thiagarajan, et al ). Retrieved July 29, 2019, from Bustang's Blog website: https:// bustangbuhari.wordpress.com/2011/08/25/four-d-model-modelpengembangan-perangkat-pembelajaran-dari-thiagarajan-dkk/

Indonesia, C. (2019). Indonesia Ranked First Travel Halal Rated World. Taken 25 July 2019 on the style of life website: https:/ / www.cnnindonesia.com/gayahidup/20190409145715-269-384592/indonesia-peringkat-pertama-wisata-halalterpopuler-dunia 
\begin{tabular}{r||r} 
Siyaha Tourism Application Development: & \\
E-Encyclopedia of Arabic Tourism in Malang, East Java, \\
Indonesia
\end{tabular} \mid R. Taufiqurrochman, Agung Prasetiyo

Kelana, I. (2017, July 18). This is the reason the Middle East is the Main Market for Halal Tourism. Retrieved July 25, 2019, from Republika Online website: https:/ / republika.co.id/share/ot9koh374

Masrafi, L. (2019). Traveler Middle East two times as much of the entire tourists inter ANTARA News Makassar. Taken July 20, 2019, from

https:/ / makassar.antaranews.com/berita/112211/wisatawan-timur-tengahdua-kali-lipat-dari-seluruh-wisman

Nauly, Y. (2019). Developments Travelers Saudi Arabia Show Trends Positive. Taken July 25, 2019, from Suryakarya.id website:

https:/ / www.suarakarya.id/detail/86715/Perkembangan-Wisatawan-ArabSaudi-Tunjukkan-Kecenderungan-Positif

Pressman, R. S. (2010). Software Engineering: A Practioner's Approach 7th Edition. New York: McGraw-Hill Higher Education.

Pressman, R. S. (2012). Engineering Tool Software - Book One, Approach Practitioner (7th ed.). Yogyakarta: Andi Publisher.

Purnamasari, D. (2017). Reading the Trend of Increasing Saudi Arabian Tourists to Bali. Taken July 20, 2019, from Tirto.id website: https:/ / tirto.id/membaca-trenpeningkatan-turis-arab-saudi-ke-bali-cjUo

S., T., Semmel, D. S., \& Semmel, M. I. (1974). Instructional Development for Training Teachers of Exceptional Children. Minnesota: Leadership Training Institute/Special Education.

Samori, Z., Salleh, N., \& Khalid, M. (2016). Current Trends in Halal Tourism: Cases on Selected Asian Countries. Tourism Management Perspective, 19, 131-136.

Sasongko, D. (2017). Travel Malang ready discordant increase in visits travelers. Taken July 25, 2019, from 25 Juli 2019, from Https:/ / malang.merdeka.com website: https:/ / malang.merdeka.com/kabar-malang/wisata-kota-malang-siapsumbang-peningkatan-kunjungan-wisatawan-170807r.html

Satriana, E. D., \& Faridah, H. D. (2018). Halal Tourism: Development, Change, and Challenge. Journal of Halal Product and Research, 1(2), 32.

https:/ / doi.org/10.20473/jhpr.vol.1-issue.2.32-43

Sugiyono. (2009). Statistics for Research. Bandung: Alfabeta.

Sugiyono. (2010). Methods Research Educational Approach Quantitative, Qualitative, and $R \mathcal{E D}$. Bandung: Alfabeta.

Susanto, J. (2012). Development of Learning Tools for Lesson Study with Cooperative Type Numbered Head Together to Increase Activities and Science Learning Outcomes in Elementary Schools. Journal of Primary Educational, 1(2) 